\title{
Learning about community capacity in the Fundy Model Forest
}

\author{
by Omer Chouinard ${ }^{1}$ and Johanne Perron ${ }^{2}$
}

The forest plays an important role in New Brunswick's economy. The Fundy Model Forest, located in southeastern New Brunswick developed a multi-stakeholder approach to public participation in sustainable forest management. This paper presents the main results of a research conducted in the year 2000 with representatives of the 31 FMF partner organizations. The objectives of the survey were mainly to verify the responsibility taken by partner organizations in term of community capacity and leadership in communities in order to develop and optimize collaborative management of forest resources. The survey was based on semi-directed interviews.

Key words: community capacity, multi-stakeholder, public participation, sustainability, forest management, consensus building, decision making, Fundy Model Forest, individual learning, organizational learning, adaptative management, non-timber values

La forêt joue un rôle important dans l'économie du Nouveau-Brunswick. La Forêt modèle de Fundy, située dans le sud-est du Nouveau-Brunswick a adopté un processus multipartite de collaboration en vue de la participation du public pour une gestion durable de la forêt. Cet article présente des résultats de recherche menée en 2000 avec des représentants de 31 organisations partenaires de la FMF. Un des objectifs de cette enquête étaient de vérifier les responsabilités prises par les partenaires en terme de capacité communautaire et de leadership dans les communautés en vue de développer et optimiser la gestion collaborative des ressources forestières.

Mots clés: Capactié de la communauté, multi-intervenants, participation publique, durabilité, aménagement forestier, établissement d'un consensus, prise de décision, Fôret modèle de Fundy, apprentissage individuel, apprentissage organisationnel, aménagement adapté, valeurs non ligneuses

\section{Introduction}

The forest plays an important role in New Brunswick's economy. In fact, New Brunswick is, proportionally, the Canadian province most dependent on industrial forestry. The Fundy Model Forest (FMF), located in southeastern New Brunswick, has developed a multi-stakeholder (Turcotte 1997) approach to public participation in sustainable forest management. The multi-stakeholder process has gained popularity as a tool used in response to resource management issues. Within the Fundy Model Forest, we consider the multi-stakeholder process an integral component of the learning process of FMF partners during community capacity-building.

The main objectives of this paper are: to establish whether or not, and why, partners and local groups took ownership of information concerning ideas for multiple uses of the forest; to determine whether or not, and why, partners and local groups came to a better understanding and appreciation of each other's values, objectives and preferences; to establish whether or not, and why, the information research project results have influenced the practices of partner organizations and local groups; and to assess the responsibility assumed by partner organizations in terms of community capacity and leadership in the development toward collaborative management of forest resources. First, we will present the Model Forest and its role. Second, we will offer theoretical aspects of community capacity. Finally, we will present community capacity-building learning via the FMF experience.

\footnotetext{
${ }^{1}$ Professor, Department of Sociology and Director of the Master Program in Environmental Studies at Université de Moncton. E-mail: chouino@UMoncton.CA

${ }^{2}$ Graduate student in Master Program on Environmental Studies at Université de Moncton.
}

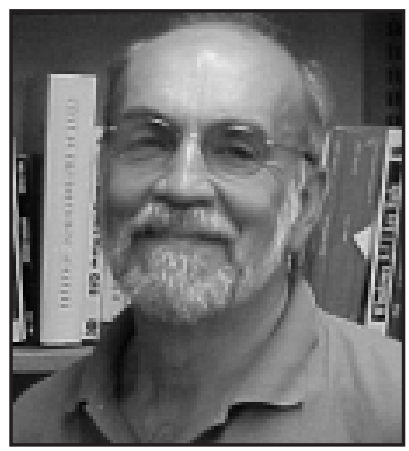

Omer Chouinard

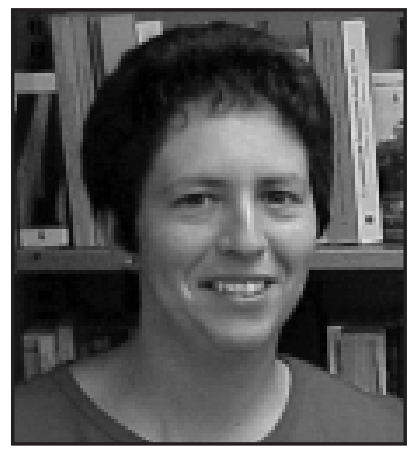

Johanne Perron

\section{Fundy Model Forest Objectives}

New Brunswick is, proportionally, the Canadian province most dependant on industrial forestry with 40 communities depending on the forest sector for over 50\% of their base employment, compared to 127 in Quebec, 7 in Nova Scotia and 337 in Canada (Beckley 1998). The territory of the FMF covers 420000 hectares and represents the Acadian forest in the Canadian National Network of Model Forests: 63\% is owned by over 5000 families (private small woodlot owners with 10 to 500 hectares each), $17 \%$ by J.D. Irving, Ltd., $5 \%$ by the Fundy National Park and the remaining 15\% represent the province's Crown Land. New Brunswick initiated a third five-year plan in 2002. The majority of FMF lands are privately owned small holdings:

"The greatest challenge to the FMF Partnership has been the development of a sustainable approach to forest management across the various land ownerships. The Fundy Model Forest vision is to ensure environmental 
sustainability and ecological integrity of the forest, while deriving sustainable social and economic benefits." 3

Canada's involvement began in 1992 following the trend of Rio de Janeiro UNCED Conference. Canada took a leadership role with different initiatives including the creation of the Model Forest. Today, twelve model forests exist across Canada supported by the Canadian Forest Service. Despite differences based on local characteristics, the model forests all focus on sustainable development. "Each model forest brings together, and forms a partnership among, individuals and organizations sharing the common goal of sustainable forest management." "Studies have shown that the success of the multi-stakeholders approach will depend of the importance of mutual learning (Brand et al. 1996, Kazi 1997, Chouinard and Perron 2000), the transmission of knowledge between this variety of actors (Kazi 1997) and collective learning (Brand et al. 1996).

\section{Aspects Of Community Capacity}

A Canadian Policy Research Networks publication (RCRPP 1998) publication has shown that the reinforcement of social cohesion will constitute a crucial element in a strategy to reestablish the Canadian social fabric. As mentioned by Beck (1998), industrial societies have suffered major changes in the last thirty years, and the structures and categories of thought on which these societies were built are no longer relevant. To help establish social ties, Granovetter and Swedberg (1994) have shown that the economic action is embedded in permanent networks of personal relationships that regularly make people come into contact with one another. Moreover, Granovetter (1973, 1985, 2000) argues strongly for the importance of social ties in economic activities: on the one hand, weak ties can facilitate innovation, while on the other strong ties can inhibit innovation. The cumulating of community involvement by social groups is called social capital. Putnam (1999) defines the concept of social capital as those aspects of collective life that make life more productive, like participation, trust and reciprocity. In 1993, in his publication on Making Democracy Work, Putnam, leaning on a study of modern Italy, argues that "the term social capital refers to features of social organizationsuch as networks, norms and trust that increase a society's productive potential" (see also Bullen and Onyx 1998a and 1998b). Scholars also recognize that mercantile economics can work thanks to networks' contributions, trust, social capital and more widely, to social relationships and structures (Lévesque et al. 2001). Community capacity "is the extent to which members of a community can work together effectively, and includes the ability to develop and sustain strong relationships, solve problems and make group decisions, and collaborate effectively to identify goals and get work done" (Mattessich and Monsey 1997). Reimer (1996, 2001), who studied rural communities, argued "social capacity refers to the ability of people to organize their assets and resources to achieve objectives they consider important. These objectives may be reactive, where people are faced with some challenge — or innovative, where new visions are established and pursued." We can also argue that the literature on environmental education's principle of pro-

\footnotetext{
${ }^{3}$ www.FundyModelForest.net

${ }^{4}$ www.modelforest.net
}

viding tools and skills helped improve community capacitybuilding by providing "ties between people, social groups and the environment" (Sauvé 2001).

\section{Methodology}

This paper presents the aspects of community capacity from research conducted in the year 2000 with representatives of the 31 FMF partner organizations. The one-hour survey was based on semi-directed interviews, and seven dimensions ${ }^{5}$ were covered. We will only consider aspects relevant to community capacity. The interviews were coded and analyzed using Atlas.TI, software developed for qualitative analysis; we used thematic analysis (Paillé 1996). We had over 600 hundred pages of manuscript. Even if we respected subject confidentiality, some people did not want their comments attributed to their organization. About 30000 inhabitants live in the FMF territory.

\section{Learning and Knowledge about Community Capacity-building in the Experience of the FMF}

Data on capacity in the FMF were classified into four categories: i) the process, ii) how to work with people (building trust), iii) forest management, and iv) scientific research.

\section{Different Aspects of Learning about Community Capacity in the FMF}

This section looks at the question: What knowledge do people gain through their participation in the FMF? The interviews showed that people and organizations gained new knowledge, skills and attitudes because of their participation in the FMF. They learned about four main themes: each other, working with people, managing the forest, and the role of knowledge in decision-making (Table 1).

\section{Learning about Partners' Values (Link of Trust)}

This sub-section answers the question: Do people gain a better understanding and appreciation of each others' values, objectives and preferences through the multi-stakeholder approach, i.e., do they "learn about each other?" First, we will look at personal learning. Then, we will see whether the representatives' learning about other partners translated into organizational learning.

Almost all interviewees reported that participation in the FMF increased their own knowledge and understanding of other partners' roles, viewpoints, objectives, values and/or needs. People learned most about industries, environmentalists, small woodlot owners, aboriginals and the Department of Natural Resources.
"You know, if I didn't understand, for example, some of the points of view before, gradually through the years I've come to understand different points of view and as I say, come to respect all of the partners."

Sometimes, better understanding of other partners made people realize they had common concerns, breaking isolation. Other

\footnotetext{
${ }^{5}$ The seven dimensions were: their organization, the organization's involvement in the FMF, information exchange, personal learning, organizational learning, the decision-making process, their perception on the FMF model of participation and decision and the transferability of the model.
} 


\begin{tabular}{|c|c|c|}
\hline Learning about social and community capacity: & $\begin{array}{l}\text { Personal } \\
\text { learning }\end{array}$ & $\begin{array}{c}\text { Organizational } \\
\text { learning }\end{array}$ \\
\hline $\begin{array}{l}\text { Learning about partners } \\
\text { - } \quad \text { Better knowledge and understanding of other viewpoints } \\
\text { Better understanding of commonalities and differences }\end{array}$ & $\begin{array}{l}X \\
X\end{array}$ & $\begin{array}{l}X \\
X\end{array}$ \\
\hline $\begin{array}{l}\text { Learning about ways to work with people } \\
\text { Problem-solving skills } \\
\text { - }\end{array}$ & $\begin{array}{l}X \\
X\end{array}$ & $\begin{array}{l}X \\
X\end{array}$ \\
\hline 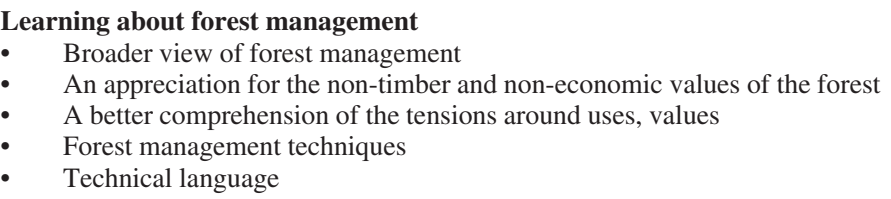 & $\begin{array}{l}X \\
X \\
X \\
X \\
X\end{array}$ & $\begin{array}{l}X \\
X \\
X \\
X\end{array}$ \\
\hline $\begin{array}{l}\text { Learning about the role of knowledge } \\
\text { - The role of practical and scientific knowledge } \\
\text { - Adaptive management }\end{array}$ & $X$ & $\mathrm{X}$ \\
\hline
\end{tabular}

times, deeper knowledge of partners led to the realization that they had divergent viewpoints they were unaware of before. It was emphasized that understanding does not necessarily mean agreeing. However, they did acknowledge other people's values and were able to understand why disagreement exists. That knowledge helped them find common ground despite any divergence of opinions.

"Through the Model Forest, the opportunity to hear other people's concerns... and we find out that the diverging viewpoints, while they still may be there, they're not as divergent as we thought. There is some common ground that allows for the discussion."

People now finally associate faces with organizations and have developed personal relationships with others, despite their differences. This is generally seen as a positive outcome. It seems that over time, people have "depersonalized" the debates and have been able to focus on the issues.

\section{"We've developed personal acquaintances and working relationships and while we still may see things vastly dif- ferent, we're able to sit down and we're able to talk about it and each better understand what the other person is talk- ing about."}

To what extent does a better understanding on the part of representatives result in a better understanding of the part of their organization as a whole? Seven representatives thought their organizations had not changed their perceptions about other partners' viewpoints. Six others thought that only involved members of their organizations learned about other partners. Four did not know whether their organizations had changed their perceptions about other partners. Finally, a total of ten representatives thought their organizations had learned about at least one other group's viewpoints (environmentalists, small woodlot owners, industry, foresters, and schools).

"We're not the only stewards of the environment anymore, you know. There are other people out there who do care about the environment and who are doing their share of the protection activity."

A few representatives stressed that learning is mutual; that, in other words, there is reciprocity; others said they hoped there was. Because mutual learning for community capacity requires direct contacts, interviewees believe that it will cease as soon as the Partnership disappears. Given its benefits, however, some stressed that whatever happens, the Partnership should continue. It was felt that mutual learning reduces and prevents conflicts. Some contrasted the FMF process to "discussions" via the media. Direct dialogue helps to clarify and learn about each other's positions, whereas the media tend to harden positions and obscure the facts. As mentioned earlier, deeper knowledge of other partners' viewpoints helps see the common concerns that can be worked on together, as well as the limits of what can be done. It is the first step toward respect and inclusion, as was emphasized by one aboriginal member:

"Initially they were wondering 'well, how can you be treated equally if we don't know what you're doing. If you expect us to, to welcome you, what have you been doing?' And that was part of the first couple of workshops that we had, was just getting to know each other. This is what we're doing, this is what the Fundy Model is doing."

The results from this section clearly show that representatives have learned a lot about other partners. Personal contacts make a big difference and help focus on issues rather than on preconceived ideas about other sectors. While representatives from different organizations may still disagree, they understand better why they do. They also have a better idea of what they can agree upon. Because learning about social capacity requires personal contacts, it was felt that organizations did not benefit as much from that aspect of learning in the FMF. Interestingly, some of the organizations that have gained a better understanding of other partners had occasion to get to know them outside the FMF. For instance, they invited other partners to give a talk to their group. 


\section{Learning about Ways to Work with People or the Process}

The interviews revealed that representatives valued their knowledge about problem-solving skills, consensus building and multistakeholder approaches. The FMF prompted a reflection about the role of practical and scientific knowledge.

\section{Problem-solving skills}

In terms of personal learning, representatives from all sectors and from nearly two thirds of the partner organizations acquired skills and tools related to group problem-solving. The mentioned skills are mostly "communication skills" such as diplomacy, listening skills, and working with divergent viewpoints. They have also learned about public participation.

"Yes sure, I've learned to listen, I've learned that other people have good ideas, I learned that... I learned to share, I've learned to work with people that have very divergent views and I think when you put it all together you can find a common ground."

\section{Consensus-building and the multi-stakeholder approaches}

Learning about consensus-building and multi-stakeholder approaches was of major importance to many interviewees. The consensus-building and multi-stakeholder approaches are usually seen as tools to share viewpoints, to find common ground and work towards a compromise, to find "common solutions to complex problems."

\section{"the (...) question of reaching a consensus and having facilitators and having a partnership approach to prob- lem-solving, I mean, that just is so new to me, I can't even tell you how stunning that is in terms of learning."}

Respondents also learned of the difficulties associated with the consensus approach. Agreement is not always clear. It is also difficult to bring one's own organization to understand how consensus was reached in response to specific issues. Organizations also see the need for multi-stakeholder forums in order to achieve their objectives.

“... for the sake of learning and the sake of educating even outside the multi-stakeholder group, I think that multistakeholder process has tremendous learning value but I think it's very difficult to manage and to make hard decisions with a multi-stakeholder group as large as it is there with using the concept of consensus."

\section{Learning about Forest Management (Transfer of Knowledge)}

Over one third of the representatives, independent of their training and experience in forestry, found that participating in the FMF broadened their perspective on forest management. As a result, they acknowledged more values than before. Some also said they now better understood the difficulties associated with conciliating various values.

"I've learned about, you know, how broad a spectrum forestry is, it's not just the trees. It's everything else."

Does the representatives' broader view of forest management translate into organizational learning? According to five inter- viewees, their organizations' view of forest management has expanded to include sustainable forest management issues and/or multiple uses. One community realized its dependence on the forest, hence, the importance of sustainability.

"Basically, we've learned, I think we've gained an appreciation for how broad and how deep sustainable forest management issues are."

Biodiversity and environment are the non-timber values most often mentioned by the interviewees. People also gained an awareness or appreciation for aesthetic and recreational values.

"I attended a meeting at the Model Forest about three or four years ago and it was six hours of science modelling, how well the pieces we were looking at would come together into a final management and one of the NGOs got up about 3:00 and began to talk about what the forest meant to her and her daughter. Completely different, you know, and it takes you back and you'll say well, you can look at it two ways, she's really way out in the left field or it's a different perspective and it's good. It is a different perspective because we all see the forest..."

Partners who were not involved in forestry reported they learned a great deal about harvesting techniques, current harvesting practices and the impacts of harvesting on the ecosystem. For their part, partners from the forestry and forestry education sectors often learned more sustainable forest management strategies and techniques (best management practices, or BMPs, ecosystem management, ecological land classification and water quality sampling techniques, for example). Various organizations learned about and benefited from some access to GIS technology. Each person brought his or her particular background to the multi-stakeholder group. Therefore, in order to communicate and to participate, people first had to learn each other's technical language and be it rooted in forest management or ecological concepts.

"I know more than I ever did before about how stands of vegetation, how stands of vegetation are exploited by foresters and what their technical approach to exploitation is about. I know, I mean I know the reasons for their antipathy towards leaving older forests in place even though to the straightforward conservationists, it seems like a terrible thing to touch it but it still seems like a terrible thing to touch it to me (inaudible). But I at least understand the thinking behind it, which I didn't before very well. I still disagree with it but that's, that's where we come from."

As mentioned, participating in the FMF helped find common ground. But it also highlighted the difficulties associated with conciliating the different uses of the forest. Some attained a better understanding of economic pressures placed on the forest and of the (mostly economic) trade-offs faced by landowners interested in sustainable forest management. The difficulties involved with implementing GFE Guidelines were also mentioned.

"I have learned a bit about the trade-offs between forest operation, profit-making and biodiversity guidelines. And 
also some of the difficulties involved with implementing them, it's not as simple as you'd think following the GFE guidelines document."

To summarize this sub-section, the FMF helped build community capacity by expanding people and organizations' view of forest management to include concerns about biodiversity and the environment. It also fostered a better appreciation of values such as aesthetics and recreation. Partners not from the forestry sector learned about the forest industry and harvesting. The FMF did not (and cannot) eliminate the tensions between the forest's different uses, but it improved the comprehension of these tensions. People from various organizations learned new technical language and acquired access to GIS technology. People from the forestry sector mentioned they learned new forest management techniques.

\section{Learning about the Role of Scientific Knowledge}

Representatives from both the industrial and scientific sectors mentioned scientific contributions to forest management and to forest industry. On the other hand, scientists found that their organizations benefited from the foresters' and the industry's practical knowledge. They also appreciated the opportunity to do applied research.

"... we certainly welcomed the specific expertise. Like it's one thing for us to, to have paper knowledge, sort of desk-bound knowledge of things like best management practices and so on, but there is so much practical experience out there, people who actually work in the field, work with the chainsaws and that type of thing that we have definitely benefited from that."

Despite mutual learning between landowners and scientists, there is much controversy over the role of science and research in decision-making. It is a theme that came up in a number of interviews with partners. Research has been regarded as beneficial by all sides of the partnership. The idea of adaptive management - to make decisions based on existing knowledge, to monitor the changes, and to adjust the knowledge base-is generally accepted. The debate centres mostly around the amount of research needed before proceeding to action on the ground. Some feel they can not put forward recommendations before research proves their proposal correct.

\section{Those Issues People Did Not Learn About}

While we asked people what they learned about, it is equally important to know what they did not learn about. We asked them what were important forest-related issues and whether or not these issues were addressed by the FMF.

It was felt that some messages were not getting through to the FMF, or that the process made it difficult to learn more about those issues. People would like to see more attention devoted to various social and economic issues, including the reduction of consumption. They want to learn more about non-timber and non-consumptive values.

Via the FMF, personal learning about community capacity resulted in a better understanding of other viewpoints, both commonalities and differences. They learned about the consensusbuilding and multi-stakeholder approaches and gained problem-solving skills. The FMF experience also contributed to broadening respondents' perception of forest management and increased their appreciation of the non-timber and non-economic values of the forest. Yet, it was felt that learning about non-timber and non-consumptive values should be more emphasized. People learned about more sustainable forest management techniques. The FMF facilitated a reflection on the role of practical and scientific knowledge as well as, to some extent, on that of adaptive management.

\section{From Personal Building to Organizational Building on Various Aspects of Community Capacity}

One of our research questions is: To what extent is the information gained in the FMF shared within partner organizations and with communities within the FMF, in order to stimulate public debate about the future of forests and forest-dependent communities? To answer our research question, we will break it up into three others. First of all, do organizations learn? What do organizations learn? And how do they learn?

\section{Do Organizations Learn?}

While all representatives felt they learned from their participation in the FMF, not all were convinced that their organizations did. Not surprisingly, individuals generally felt they learned much more than their organizations because of their direct involvement. Yet, many thought that their organizations at least gained some new knowledge on community capacity because of the FMF.

\section{What do Organizations Learn?}

We differentiated personal from organizational learning in the previous section and in Table 1 . The interviews showed that all types of knowledge were transferred to some degree to organizations. The role of science for application on the ground was a point brought up as organizational learning more often than as personal learning.

\section{How do Organizations Learn?}

In order to answer this question, we asked representatives "How do you keep your organization informed about FMF activities?" In other words, what are their means of communication? Various means of communication are used by FMF representative to transfer information to their organizations.

Partners certainly use FMF materials and communication tools, whether they are the printed material, the Web site, the annual general meetings, videos or electronic material. They integrate the material provided by the FMF within their organizations' communication channels such as newsletters, email, mailings and reports, meetings and training sessions. Some organizations benefit from adapted tools of communication such as the Best Management Practices (BMPs) Manual, the schoolteachers' in-service, or the school curriculum.

Transferring information to organizations is difficult. Direct involvement is key to learning and organizations do not usually participate as a whole.

"It's difficult to bring a group along with you because it's such a process (...) It's hard enough to, to be... when you're actually being a part of the process to realize what brought you to this consensus to go back to a group and then try to bring them there..." 
Communication with the broader community is rather limited. It depends on the organization's mission. Those that, by definition, are concerned with the local community, (municipalities or community-oriented organizations) or with people's education, (formal and non-formal) tended to involve the broader community.

\section{Conclusion}

The basis of community capacity-building permits us to conclude that learned objectives of the various FMF partners initiated via the multi-stakeholder approach allows people to develop trust-based ties thereby bringing them closer together. Mutual learning results show that the representatives of FMF groups learned a great deal about the other partners; representatives of different organizations may still have certain divergence of opinions; however, they have gained a better understanding of the reasons behind their differences of opinion. With respect to learning about the process, about how to work with people, or even resolve conflicts, the consensual approach and PMC are generally understood to be tools of community capacity used to share viewpoints and find common solutions to complex problems. As for knowledge transmission, we have noted that the FMF helped open up perspectives of forest management, organizations, and people to include biodiversity and environmental preoccupations. However, if the FMF did not succeed in eliminating tensions between the forest's various users, it did allow for an understanding of these tensions. Finally, the role of science and research is generally perceived to be beneficial. We can thus say that FMF participants, regardless of their differences, established work relations with their "partners."

In other words, the complexity of forest ecosystems and the debate on public participation in forest management require a variety of institutions, enterprises and a broad spectrum of groups in civil society to explore alternatives for forest sustainability. In the context of multi-stakeholder process of the FMF, the partners learn about consensus-building and decisionmaking. Learning about diversity, from the technical language of practitioners to people's values, helps to understand disagreements, to establish ties and to find solutions to complex problems.

In contrast, the transmission of individual learning between partners and their organizations, even when all persons interviewed claim to have bettered their own knowledge and understanding of other partners' roles, viewpoints, objectives, values, and needs, also claim to have learned much more than their organizations have. Their learning is transferred only with difficulty to the organizational level, direct contacts being judged primordial at the FMF in the acquisition of new knowledge. The FMF Partnership has allowed organizations to create new social networks outside the FMF. Access to information and learning new information via the FMF Partnership, both on individual and organizational levels, are very important factors motivating participation and fostering community capacity-building.

\section{Acknowledgement}

Thanks to Sabrina DiMarco for her advice and comments.

\section{References}

Beck, U., 1998. Le conflit de deux modernités et la question de la disparition des solidarités. Lien social et Politiques-RIAC no. 39: 15-25.
Beckley, T. 1998. Community input into forest policy and planning. Presentation to the "Empowering the Public" Panel at the National Forest Congress, 1 May, 1998. Ottawa.

Brand, D.G., O.T. Bouman, L. Bouthillier, W. Kessler and L. Lapierre. 1996. The Model Forest Concept. A Model for the Future Forest Management. Environmental Reviews 4(1): 65-90.

Bullen, P. and J. Onyx. 1998. Measuring Social Capital in Five Communities in NSW: an Analysis. Center for Australian Community Organization and Management (CACOM), T. 1. University of Technology, Sydney. 59 p. www.mapl.com.au/A2.htm. 10 p.

Bullen, P. and J. Onyx. 1998. Measuring Social Capital in Five Communities in NSW: a Practitioners' Guide. Center for Australian Community Organization and Management (CACOM), T. 2. University of Technology, Sydney. 99 p. www.mapl.com.au/A2.htm. 10 p.

Chouinard, O. and J. Perron. 2000. Mutual Learning and Transfer of Knowledge at the Fundy Model Forest. Fundy Model Forest, Sussex, New Brunswick. 44 p.

Granovetter, M. 1973. The strength of weak ties. American Journal of Sociology 78(6): 1360-1380.

Granovetter, M. 1985. Economic action and social structure: the problem of embeddedness. American Journal of Sociology (Nov): 481-510.

Granovetter, M. 2000. Le marché autrement. Les réseaux dans l'économie. Desclée de Brouwer, Paris.

Granovetter, M. and R. Swedberg. 1994. Business groups. In N.J Smelser and R. Swdberg (eds.). The Handbook of Economic Sociology. pp. 453-475. Princeton University Press/Russell Sage Foundation, Princeton and New York.

Kazi, J. 1997. Les enjeux de la participation du public en gestion forestière par la cartographie cognitive : le cas de Charlevoix, Mémoire de Maîtrise. Université Laval, Ste-Foy.

Lévesque, B., G.L. Bourque and É. Forgues. 2001. La nouvelle sociologie économique. Desclée de Brouwer, Paris. 268 p.

Mattessich, P. and B. Monsey. 1997. Community Building. What makes it work: A review of Factors Influencing Successful Community Building. Amherst H. Wilder Foundation, St. Paul, MN. 112 p.

Paillé, P. 1996. De l'analyse qualitative en général et de l'analyse thématique en particulier. In J. Archanbault and P. Paillé (eds.). La recherche qualitative dans la santé, Recherches qualitatives no.15: 181-194.

Putnam, R.D. 1993. Making Democracy Work: Civic Traditions in Modern Italy. Princeton University Press, Princeton, N.J. 240 p.

Putnam, R.D. 1999. Le déclin du capital social aux États-Unis. Lien social et Politiques-RIAC no. 41. p.14.

Reimer, W.C. 1997. Informal Social Networks and Voluntary Associations in non-metropolitan Canada. In Changing Rural Institutions: A Canadian Perspective. pp. 89-104. Brandon University for the Canadian Rural Revitalization Foundation,

Reimer, W.C. 2001. Building Capacity in the New Rural Economy, Letter of Intent: SSHRC Initiative on the New Economy, Collaborative Research Initiatives Program, Dept. of Sociology and Anthropology, Concordia University. 12 p. See also www.crrf.ca , http://nre.concordia.ca , and http://alcor.concordia.ca/ reimer/

Réseaux canadiens de recherches en politiques publiques (RCRPP) (Canadian Policy Research Networks. 1998. Les contours de la cohésion sociale. (Fiche documentaire). Speech presented at the conference: La Recherche sur les politiques : créer les liens. Organized by the Secrétariat de la recherche sur les politiques, Ottawa, October 1, 1998.

Sauvé, L. 2001. Éducation et environnement : construire l'espoir, sans naïveté. Un monde vert, nouvelle stratégie, nouvelles pratiques. Possible no. 1, Winter: 92-106.

Turcotte, M.-F. 1997. Prise de décision par consensus : leçons d'un cas en environnement. l'Harmattan, Paris/Montréal. 